\title{
Coupled best proximity point theorems for $\alpha-\psi$-proximal contractive multimaps
}

Jamnian Nantadilok

"Correspondence: jamnian52@lpru.ac.th Department of Mathematics, Faculty of Science, Lampang Rajabhat University, Lampang, 52100, Thailand

\begin{abstract}
In this paper, we establish coupled best proximity point theorems for multivalued mappings. Our results extend some recent results by Ali et al. (Abstr. Appl. Anal. 2014:181598, 2014) as well as other results in the literature. We also give examples to support our main results.
\end{abstract}

MSC: $47 \mathrm{H} 09 ; 47 \mathrm{H} 10$

Keywords: proximal contractive multivalued mapping; best proximity point; coupled fixed point; coupled best proximity point 
$\mathrm{K}(X)$ is the set of all nonempty compact subsets of $X$. For every $A, B \in \mathrm{CL}(X)$, let

$$
H(A, B)= \begin{cases}\max \left\{\sup _{x \in A} d(x, B), \sup _{y \in B} d(y, A)\right\} & \text { if the maximum exists; } \\ \infty & \text { otherwise. }\end{cases}
$$

Such a map $H$ is called the generalized Hausdorff metric induced by $d$. A point $x^{*} \in X$ is said to be the best proximity point of a mapping $T: A \rightarrow B$ if $d\left(x^{*}, T x^{*}\right)=\operatorname{dist}(A, B)$. When $A=B$, the best proximity point is essentially the fixed point of the mapping $T$.

Definition 1.1 (see [34]) Let $(A, B)$ be a pair of nonempty subsets of a metric space $(X, d)$ with $A_{0} \neq \emptyset$. Then the pair $(A, B)$ is said to have the weak $P$-property if and only if, for any $x_{1}, x_{2} \in A$ and $y_{1}, y_{2} \in B$,

$$
\left.\begin{array}{l}
d\left(x_{1}, y_{1}\right)=\operatorname{dist}(A, B), \\
d\left(x_{2}, y_{2}\right)=\operatorname{dist}(A, B)
\end{array}\right\} \Rightarrow d\left(x_{1}, x_{2}\right) \leq d\left(y_{1}, y_{2}\right)
$$

Let $\Psi$ denote the set of all functions $\psi:[0, \infty) \rightarrow[0, \infty)$ satisfying the following properties:

(a) $\psi$ is monotone nondecreasing;

(b) $\sum_{n=1}^{\infty} \psi^{n}(t)<\infty$ for each $t>0$.

Definition 1.2 (see [21]) An element $x^{*} \in A$ is said to be the best proximity point of a multivalued nonself mapping $T$ if $D\left(x^{*}, T x^{*}\right)=\operatorname{dist}(A, B)$.

Definition 1.3 (see [42]) Let $A$ and $B$ be two nonempty subsets of a metric space $(X, d)$. A mapping $T: A \rightarrow 2^{B} \backslash \emptyset$ is called $\alpha$-proximal admissible if there exists a mapping $\alpha$ : $A \times A \rightarrow[0, \infty)$ such that

$$
\left.\begin{array}{r}
\alpha\left(x_{1}, x_{2}\right) \geq 1, \\
d\left(u_{1}, y_{1}\right)=\operatorname{dist}(A, B), \\
d\left(u_{2}, y_{2}\right)=\operatorname{dist}(A, B)
\end{array}\right\} \Rightarrow \alpha\left(u_{1}, u_{2}\right) \geq 1,
$$

where $x_{1}, x_{2}, u_{1}, u_{2} \in A, y_{1} \in T x_{1}$ and $y_{2} \in T x_{2}$.

Definition 1.4 (see [42]) Let $A$ and $B$ be two nonempty subsets of a metric space $(X, d)$. A mapping $T: A \rightarrow \mathrm{CL}(B)$ is said to be an $\alpha-\psi$-proximal contraction if there exist two functions $\psi \in \Psi$ and $\alpha: A \times A \rightarrow[0, \infty)$ such that

$$
\alpha(x, y) H(T x, T y) \leq \psi(d(x, y)), \quad \forall x, y \in A
$$

Lemma 1.5 (see [11]) Let $(X, d)$ be a metric space and $B \in \mathrm{CL}(X)$. Then, for each $x \in X$ with $d(x, B)>0$ and $q>1$, there exists an element $b \in B$ such that

$$
d(x, b)<q d(x, B)
$$

(C) If $\left\{x_{n}\right\}$ is a sequence in $A$ such that $\alpha\left(x_{n}, x_{n+1}\right) \geq 1$ for all $n$ and $x_{n} \rightarrow x \in A$ as $n \rightarrow \infty$, then there exists a subsequence $\left\{x_{n_{k}}\right\}$ of $\left\{x_{n}\right\}$ such that $\alpha\left(x_{n_{k}}, x\right) \geq 1$ for all $k$. 
The main results of Ali et al. in [42] are the following.

Theorem 1.6 (see [42]) Let $A$ and $B$ be two nonempty closed subsets of a complete metric space $(X, d)$ such that $A_{0}$ is nonempty. Let $\alpha: A \times A \rightarrow[0, \infty)$ and $\psi \in \Psi$ be a strictly increasing map. Suppose that $T: A \rightarrow \mathrm{CL}(B)$ is a mapping satisfying the following conditions:

(i) $T x \subseteq B_{0}$ for each $x \in A_{0}$ and $(A, B)$ satisfies the weak P-property;

(ii) $T$ is an $\alpha$-proximal admissible map;

(iii) there exist elements $x_{0}, x_{1}$ in $A_{0}$ and $y_{1} \in T x_{0}$ such that

$$
d\left(x_{1}, y_{1}\right)=d(A, B), \quad \alpha\left(x_{0}, x_{1}\right) \geq 1
$$

(iv) $T$ is a continuous $\alpha-\psi$-proximal contraction.

Then there exists an element $x^{*} \in A_{0}$ such that

$$
D\left(x^{*}, T x^{*}\right)=\operatorname{dist}(A, B) .
$$

Theorem 1.7 (see [42]) Let $A$ and $B$ be two nonempty closed subsets of a complete metric space $(X, d)$ such that $A_{0}$ is nonempty. Let $\alpha: A \times A \rightarrow[0, \infty)$ and let $\psi \in \Psi$ be a strictly increasing map. Suppose that $T: A \rightarrow \mathrm{CL}(B)$ is a mapping satisfying the following conditions:

(i) $T x \subseteq B_{0}$ for each $x \in A_{0}$ and $(A, B)$ satisfies the weak P-property;

(ii) $T$ is an $\alpha$-proximal admissible map;

(iii) there exist elements $x_{0}, x_{1}$ in $A_{0}$ and $y_{1} \in T x_{0}$ such that

$$
d\left(x_{1}, y_{1}\right)=d(A, B), \quad \alpha\left(x_{0}, x_{1}\right) \geq 1
$$

(iv) property (C) holds and $T$ is an $\alpha$ - $\psi$-proximal contraction.

Then there exists an element $x^{*} \in A_{0}$ such that

$$
D\left(x^{*}, T x^{*}\right)=\operatorname{dist}(A, B) .
$$

The purpose of this paper is to extend the recent results of Ali et al. [42] to a coupled best proximity point of nonself multivalued mappings.

\section{Main results}

We begin this section by introducing the following definitions.

Definition 2.1 Let $A$ and $B$ be two nonempty subsets of a metric space $(X, d)$. A mapping $T: A \times A \rightarrow 2^{B} \backslash \emptyset$ is called $\alpha$-proximal admissible if there exists a mapping $\alpha: A \times A \rightarrow$ $[0, \infty)$ such that

$$
\left.\begin{array}{r}
\alpha\left(x_{1}, x_{2}\right) \geq 1, \\
d\left(w_{1}, u_{1}\right)=\operatorname{dist}(A, B), \\
d\left(w_{2}, u_{2}\right)=\operatorname{dist}(A, B)
\end{array}\right\} \quad \Rightarrow \quad \alpha\left(w_{1}, w_{2}\right) \geq 1
$$


where $x_{1}, x_{2}, w_{1}, w_{2}, y_{1}, y_{2} \in A, u_{1} \in T\left(x_{1}, y_{1}\right)$ and $u_{2} \in T\left(x_{2}, y_{2}\right)$, and

$$
\left.\begin{array}{r}
\alpha\left(y_{1}, y_{2}\right) \geq 1, \\
d\left(w_{1}^{\prime}, v_{1}\right)=\operatorname{dist}(A, B), \\
d\left(w_{2}^{\prime}, v_{2}\right)=\operatorname{dist}(A, B)
\end{array}\right\} \quad \Rightarrow \quad \alpha\left(w_{1}^{\prime}, w_{2}^{\prime}\right) \geq 1,
$$

where $y_{1}, y_{2}, w_{1}^{\prime}, w_{2}^{\prime}, x_{1}, x_{2} \in A, v_{1} \in T\left(y_{1}, x_{1}\right)$ and $v_{2} \in T\left(y_{2}, x_{2}\right)$.

Definition 2.2 Let $A$ and $B$ be two nonempty subsets of a metric space $(X, d)$. A mapping $T: A \times A \rightarrow \mathrm{CL}(B)$ is said to be an $\alpha-\psi$-proximal contraction if there exist two functions $\psi \in \Psi$ and $\alpha: A \times A \rightarrow[0, \infty)$ such that

$$
\alpha(x, y) H\left(T\left(x, x^{\prime}\right), T\left(y, y^{\prime}\right)\right) \leq \psi(d(x, y)), \quad \forall x, x^{\prime}, y, y^{\prime} \in A .
$$

Definition 2.3 An element $\left(x^{*}, y^{*}\right) \in A \times A$ is said to be the coupled best proximity point of a multivalued nonself mapping $T$ if $D\left(x^{*}, T\left(x^{*}, y^{*}\right)\right)=\operatorname{dist}(A, B)$ and $D\left(y^{*}, T\left(y^{*}, x^{*}\right)\right)=$ $\operatorname{dist}(A, B)$.

The following are our main results.

Theorem 2.4 Let $A$ and $B$ be two nonempty closed subsets of a complete metric space $(X, d)$ such that $A_{0}$ is nonempty. Let $\alpha: A \times A \rightarrow[0, \infty)$ and let $\psi \in \Psi$ be a strictly increasing map. Suppose that $T: A \times A \rightarrow \mathrm{CL}(B)$ is a mapping satisfying the following conditions:

(i) $T(x, y) \subseteq B_{0}$ for each $x, y \in A_{0}$ and $(A, B)$ satisfies the weak P-property;

(ii) $T$ is an $\alpha$-proximal admissible map;

(iii) there exist elements $\left(x_{0}, y_{0}\right),\left(x_{1}, y_{1}\right)$ in $A_{0} \times A_{0}$ and $u_{1} \in T\left(x_{0}, y_{0}\right), v_{1} \in T\left(y_{0}, x_{0}\right)$ such that

$$
\begin{array}{ll}
d\left(x_{1}, u_{1}\right)=d(A, B), & \alpha\left(x_{0}, x_{1}\right) \geq 1 \quad \text { and } \\
d\left(y_{1}, v_{1}\right)=d(A, B), & \alpha\left(y_{0}, y_{1}\right) \geq 1 ;
\end{array}
$$

(iv) $T$ is a continuous $\alpha-\psi$-proximal contraction.

Then there exists an element $\left(x^{*}, y^{*}\right) \in A_{0} \times A_{0}$ such that

$$
\begin{aligned}
& D\left(x^{*}, T\left(x^{*}, y^{*}\right)\right)=\operatorname{dist}(A, B) \text { and } \\
& D\left(y^{*}, T\left(y^{*}, x^{*}\right)\right)=\operatorname{dist}(A, B) .
\end{aligned}
$$

Proof From condition (iii), there exist elements $\left(x_{0}, y_{0}\right),\left(x_{1}, y_{1}\right)$ in $A_{0} \times A_{0}$ and $u_{1} \in$ $T\left(x_{0}, y_{0}\right), v_{1} \in T\left(y_{0}, x_{0}\right)$ such that

$$
\begin{array}{ll}
d\left(x_{1}, u_{1}\right)=\operatorname{dist}(A, B), & \alpha\left(x_{0}, x_{1}\right) \geq 1 \quad \text { and } \\
d\left(y_{1}, v_{1}\right)=\operatorname{dist}(A, B), & \alpha\left(y_{0}, y_{1}\right) \geq 1 .
\end{array}
$$


Assume that $u_{1} \notin T\left(x_{1}, y_{1}\right), v_{1} \notin T\left(y_{1}, x_{1}\right)$; for otherwise $\left(x_{1}, y_{1}\right)$ is the coupled best proximity point. From condition (iv), we have

$$
\begin{aligned}
0 & <d\left(u_{1}, T\left(x_{1}, y_{1}\right)\right) \leq H\left(T\left(x_{0}, y_{0}\right), T\left(x_{1}, y_{1}\right)\right) \\
& \leq \alpha\left(x_{0}, x_{1}\right) H\left(T\left(x_{0}, y_{0}\right), T\left(x_{1}, y_{1}\right)\right) \\
& \leq \psi\left(d\left(x_{0}, x_{1}\right)\right)
\end{aligned}
$$

and

$$
\begin{aligned}
0 & <d\left(v_{1}, T\left(y_{1}, x_{1}\right)\right) \leq H\left(T\left(y_{0}, x_{0}\right), T\left(y_{1}, x_{1}\right)\right) \\
& \leq \alpha\left(y_{0}, y_{1}\right) H\left(T\left(y_{0}, x_{0}\right), T\left(y_{1}, x_{1}\right)\right) \\
& \leq \psi\left(d\left(y_{0}, y_{1}\right)\right) .
\end{aligned}
$$

For $q, q^{\prime}>1$, it follows from Lemma 1.5 that there exist $u_{2} \in T\left(x_{1}, y_{1}\right)$ and $v_{2} \in T\left(y_{1}, x_{1}\right)$ such that

$$
\begin{aligned}
& 0<d\left(u_{1}, u_{2}\right)<q d\left(u_{1}, T\left(x_{1}, y_{1}\right)\right) \quad \text { and } \\
& 0<d\left(v_{1}, v_{2}\right)<q^{\prime} d\left(v_{1}, T\left(y_{1}, x_{1}\right)\right) .
\end{aligned}
$$

From (13), (14) and (15), we have

$$
0<d\left(u_{1}, u_{2}\right)<q d\left(u_{1}, T\left(x_{1}, y_{1}\right)\right) \leq q \psi\left(d\left(x_{0}, x_{1}\right)\right)
$$

and

$$
0<d\left(v_{1}, v_{2}\right)<q^{\prime} d\left(v_{1}, T\left(y_{1}, x_{1}\right)\right) \leq q^{\prime} \psi\left(d\left(y_{0}, y_{1}\right)\right) .
$$

As $u_{2} \in T\left(x_{1}, y_{1}\right) \subseteq B_{0}$, there exists $x_{2} \neq x_{1} \in A_{0}$ such that

$$
d\left(x_{2}, u_{2}\right)=\operatorname{dist}(A, B)
$$

and as $v_{2} \in T\left(y_{1}, x_{1}\right) \subseteq B_{0}$, there exists $y_{2} \neq y_{1} \in A_{0}$ such that

$$
d\left(y_{2}, v_{2}\right)=\operatorname{dist}(A, B)
$$

for otherwise $\left(x_{1}, y_{1}\right)$ is the coupled best proximity point. As $(A, B)$ satisfies the weak $P$ property, from (12), (18) and (19) we have

$$
\begin{aligned}
& 0<d\left(x_{1}, x_{2}\right) \leq d\left(u_{1}, u_{2}\right) \quad \text { and } \\
& 0<d\left(y_{1}, y_{2}\right) \leq d\left(v_{1}, v_{2}\right) .
\end{aligned}
$$

From (16), (17) and (20) we have

$$
\begin{aligned}
& 0<d\left(x_{1}, x_{2}\right) \leq d\left(u_{1}, u_{2}\right)<q d\left(u_{1}, T\left(x_{1}, y_{1}\right)\right) \leq q \psi\left(d\left(x_{0}, x_{1}\right)\right) \quad \text { and } \\
& 0<d\left(y_{1}, y_{2}\right) \leq d\left(v_{1}, v_{2}\right)<q^{\prime} d\left(v_{1}, T\left(y_{1}, x_{1}\right)\right) \leq q^{\prime} \psi\left(d\left(y_{0}, y_{1}\right)\right) .
\end{aligned}
$$


Since $\psi$ is strictly increasing, we have

$$
\begin{aligned}
& \psi\left(d\left(x_{1}, x_{2}\right)\right)<\psi\left(q \psi\left(d\left(x_{0}, x_{1}\right)\right)\right) \quad \text { and } \\
& \psi\left(d\left(y_{1}, y_{2}\right)\right)<\psi\left(q^{\prime} \psi\left(d\left(y_{0}, y_{1}\right)\right)\right) .
\end{aligned}
$$

Put

$$
\begin{aligned}
& q_{1}=\psi\left(q \psi\left(d\left(x_{0}, x_{1}\right)\right)\right) / \psi\left(d\left(x_{1}, x_{2}\right)\right), \\
& q_{1}^{\prime}=\psi\left(q^{\prime} \psi\left(d\left(y_{0}, y_{1}\right)\right)\right) / \psi\left(d\left(y_{1}, y_{2}\right)\right) .
\end{aligned}
$$

We also have

$$
\alpha\left(x_{0}, x_{1}\right) \geq 1, \quad d\left(x_{1}, u_{1}\right)=\operatorname{dist}(A, B) \quad \text { and } \quad d\left(x_{2}, u_{2}\right)=\operatorname{dist}(A, B)
$$

and

$$
\alpha\left(y_{0}, y_{1}\right) \geq 1, \quad d\left(y_{1}, v_{1}\right)=\operatorname{dist}(A, B) \quad \text { and } \quad d\left(y_{2}, v_{2}\right)=\operatorname{dist}(A, B)
$$

Since $T$ is an $\alpha$-proximal admissible, then $\alpha\left(x_{1}, x_{2}\right) \geq 1$ and $\alpha\left(y_{1}, y_{2}\right) \geq 1$. Thus we have

$$
\begin{array}{ll}
d\left(x_{2}, u_{2}\right)=\operatorname{dist}(A, B), & \alpha\left(x_{1}, x_{2}\right) \geq 1 \quad \text { and } \\
d\left(y_{2}, v_{2}\right)=\operatorname{dist}(A, B), & \alpha\left(y_{1}, y_{2}\right) \geq 1 .
\end{array}
$$

Assume that $u_{2} \notin T\left(x_{2}, y_{2}\right)$ and $v_{2} \notin T\left(y_{2}, x_{2}\right)$; for otherwise $\left(x_{2}, y_{2}\right)$ is the coupled best proximity point. From condition (iv) we have

$$
\begin{aligned}
0 & <d\left(u_{2}, T\left(x_{2}, y_{2}\right)\right) \leq H\left(T\left(x_{1}, y_{1}\right), T\left(x_{2}, y_{2}\right)\right) \\
& \leq \alpha\left(x_{1}, x_{2}\right) H\left(T\left(x_{1}, y_{1}\right), T\left(x_{2}, y_{2}\right)\right) \\
& \leq \psi\left(d\left(x_{1}, x_{2}\right)\right)
\end{aligned}
$$

and

$$
\begin{aligned}
0 & <d\left(v_{2}, T\left(y_{2}, x_{2}\right)\right) \leq H\left(T\left(y_{1}, x_{1}\right), T\left(y_{2}, x_{2}\right)\right) \\
& \leq \alpha\left(y_{1}, y_{2}\right) H\left(T\left(y_{1}, x_{1}\right), T\left(y_{2}, x_{2}\right)\right) \\
& \leq \psi\left(d\left(y_{1}, y_{2}\right)\right) .
\end{aligned}
$$

For $q_{1}, q_{1}^{\prime}>1$, it follows from Lemma 1.5 that there exist $u_{3} \in T\left(x_{2}, y_{2}\right)$ and $v_{3} \in T\left(y_{2}, x_{2}\right)$ such that

$$
\begin{aligned}
& 0<d\left(u_{2}, u_{3}\right)<q_{1} d\left(u_{2}, T\left(x_{2}, y_{2}\right)\right), \\
& 0<d\left(v_{2}, v_{3}\right)<q_{1}^{\prime} d\left(v_{2}, T\left(y_{2}, x_{2}\right)\right) .
\end{aligned}
$$


From (23), (24) and (25) we have

$$
\begin{aligned}
0 & <d\left(u_{2}, u_{3}\right)<q_{1} d\left(u_{2}, T\left(x_{2}, y_{2}\right)\right) \\
& \leq q_{1} \psi\left(d\left(x_{1}, x_{2}\right)\right) \\
& =\psi\left(q \psi\left(d\left(x_{0}, x_{1}\right)\right)\right)
\end{aligned}
$$

and

$$
\begin{aligned}
0 & <d\left(v_{2}, v_{3}\right)<q_{1}^{\prime} d\left(v_{2}, T\left(y_{2}, x_{2}\right)\right) \\
& \leq q_{1}^{\prime} \psi\left(d\left(y_{1}, y_{2}\right)\right) \\
& =\psi\left(q^{\prime} \psi\left(d\left(y_{0}, y_{1}\right)\right)\right) .
\end{aligned}
$$

As $u_{3} \in T\left(x_{2}, y_{2}\right) \in B_{0}$, there exists $x_{3} \neq x_{2} \in A_{0}$ such that

$$
d\left(x_{3}, u_{3}\right)=\operatorname{dist}(A, B)
$$

and as $v_{3} \in T\left(y_{2}, x_{2}\right) \in B_{0}$, there exists $y_{3} \neq y_{2} \in A_{0}$ such that

$$
d\left(y_{3}, v_{3}\right)=\operatorname{dist}(A, B)
$$

for otherwise $\left(x_{2}, y_{2}\right)$ is the coupled best proximity point. As $(A, B)$ satisfies the weak $P$ property, from (22), (28) and (29) we have

$$
\begin{aligned}
& 0<d\left(x_{2}, x_{3}\right) \leq d\left(u_{2}, u_{3}\right), \\
& 0<d\left(y_{2}, y_{3}\right) \leq d\left(v_{2}, v_{3}\right) .
\end{aligned}
$$

From (26), (27) and (30) we have

$$
\begin{aligned}
0 & <d\left(x_{2}, x_{3}\right)<q_{1} d\left(u_{2}, T\left(x_{2}, y_{2}\right)\right) \\
& \leq q_{1} \psi\left(d\left(x_{1}, x_{2}\right)\right) \\
& =\psi\left(q \psi\left(d\left(x_{0}, x_{1}\right)\right)\right)
\end{aligned}
$$

and

$$
\begin{aligned}
0 & <d\left(y_{2}, y_{3}\right)<q_{1}^{\prime} d\left(v_{2}, T\left(y_{2}, x_{2}\right)\right) \\
& \leq q_{1}^{\prime} \psi\left(d\left(y_{1}, y_{2}\right)\right) \\
& =\psi\left(q^{\prime} \psi\left(d\left(y_{0}, y_{1}\right)\right)\right) .
\end{aligned}
$$

Since $\psi$ is strictly increasing, we have

$$
\psi\left(d\left(x_{2}, x_{3}\right)\right)<\psi^{2}\left(q \psi\left(d\left(x_{0}, x_{1}\right)\right)\right) \text { and } \psi\left(d\left(y_{2}, y_{3}\right)\right)<\psi^{2}\left(q^{\prime} \psi\left(d\left(y_{0}, y_{1}\right)\right)\right) \text {. }
$$


Put

$$
\begin{aligned}
& q_{2}=\psi^{2}\left(q \psi\left(d\left(x_{0}, x_{1}\right)\right)\right) / \psi\left(d\left(x_{2}, x_{3}\right)\right), \\
& q_{2}^{\prime}=\psi^{2}\left(q^{\prime} \psi\left(d\left(y_{0}, y_{1}\right)\right)\right) / \psi\left(d\left(y_{2}, y_{3}\right)\right) .
\end{aligned}
$$

We also have

$$
\alpha\left(x_{1}, x_{2}\right) \geq 1, \quad d\left(x_{2}, u_{2}\right)=\operatorname{dist}(A, B) \quad \text { and } \quad d\left(x_{3}, u_{3}\right)=\operatorname{dist}(A, B)
$$

and

$$
\alpha\left(y_{1}, y_{2}\right) \geq 1, \quad d\left(y_{2}, v_{2}\right)=\operatorname{dist}(A, B) \quad \text { and } \quad d\left(y_{3}, v_{3}\right)=\operatorname{dist}(A, B) \text {. }
$$

Since $T$ is an $\alpha$-proximal admissible, then $\alpha\left(x_{2}, x_{3}\right) \geq 1$ and $\alpha\left(y_{2}, y_{3}\right) \geq 1$, respectively. Thus we have

$$
\begin{array}{ll}
d\left(x_{3}, u_{3}\right)=\operatorname{dist}(A, B), & \alpha\left(x_{2}, x_{3}\right) \geq 1 \quad \text { and } \\
d\left(y_{3}, v_{3}\right)=\operatorname{dist}(A, B), & \alpha\left(y_{2}, y_{3}\right) \geq 1 .
\end{array}
$$

Continuing in the same process, we get sequences $\left\{x_{n}\right\},\left\{y_{n}\right\}$ in $A_{0}$ and $\left\{u_{n}\right\},\left\{v_{n}\right\}$ in $B_{0}$, where $u_{n} \in T\left(x_{n-1}, y_{n-1}\right)$ and $v_{n} \in T\left(y_{n-1}, x_{n-1}\right)$ for each $n \in \mathbb{N}$, such that

$$
\begin{array}{ll}
d\left(x_{n+1}, u_{n+1}\right)=\operatorname{dist}(A, B), & \alpha\left(x_{n}, x_{n+1}\right) \geq 1 \quad \text { and } \\
d\left(y_{n+1}, v_{n+1}\right)=\operatorname{dist}(A, B), & \alpha\left(y_{n}, y_{n+1}\right) \geq 1
\end{array}
$$

and

$$
\begin{aligned}
& d\left(u_{n+1}, u_{n+2}\right)<\psi^{n}\left(q \psi\left(d\left(x_{0}, x_{1}\right)\right)\right) \quad \text { and } \\
& d\left(v_{n+1}, v_{n+2}\right)<\psi^{n}\left(q^{\prime} \psi\left(d\left(y_{0}, y_{1}\right)\right)\right) .
\end{aligned}
$$

As $u_{n+2} \in T\left(x_{n+1}, y_{n+1}\right) \in B_{0}$, there exists $x_{n+2} \neq x_{n+1} \in A_{0}$ such that

$$
d\left(x_{n+2}, u_{n+2}\right)=\operatorname{dist}(A, B)
$$

and as $v_{n+2} \in T\left(y_{n+1}, x_{n+1}\right) \in B_{0}$, there exists $y_{n+2} \neq y_{n+1} \in A_{0}$ such that

$$
d\left(y_{n+2}, v_{n+2}\right)=\operatorname{dist}(A, B) .
$$

Since $(A, B)$ satisfies the weak $P$-property, from (35), (37) and (38) we have

$$
d\left(x_{n+1}, x_{n+2}\right) \leq d\left(u_{n+1}, u_{n+2}\right) \quad \text { and } \quad d\left(y_{n+1}, y_{n+2}\right) \leq d\left(v_{n+1}, v_{n+2}\right) .
$$

Thus, from (36) we have

$$
\begin{aligned}
& d\left(x_{n+1}, x_{n+2}\right)<\psi^{n}\left(q \psi\left(d\left(x_{0}, x_{1}\right)\right)\right) \quad \text { and } \\
& d\left(y_{n+1}, y_{n+2}\right)<\psi^{n}\left(q^{\prime} \psi\left(d\left(y_{0}, y_{1}\right)\right)\right) .
\end{aligned}
$$


Now, we shall prove that $\left\{x_{n}\right\}$ and $\left\{y_{n}\right\}$ are Cauchy sequences in $A$. Let $\epsilon>0$ be fixed. Since $\sum_{n=1}^{\infty} \psi^{n}\left(q \psi\left(d\left(x_{0}, x_{1}\right)\right)\right)<\infty$ and $\sum_{n=1}^{\infty} \psi^{n}\left(q^{\prime} \psi\left(d\left(y_{0}, y_{1}\right)\right)\right)<\infty$, there exist some positive integers $h=h(\epsilon)$ and $h^{\prime}=h^{\prime}(\epsilon)$ such that

$$
\sum_{k \geq h}^{\infty} \psi^{k}\left(q \psi\left(d\left(x_{0}, x_{1}\right)\right)\right)<\epsilon
$$

and

$$
\sum_{k \geq h^{\prime}}^{\infty} \psi^{k}\left(q^{\prime} \psi\left(d\left(y_{0}, y_{1}\right)\right)\right)<\epsilon
$$

respectively. For $m>n>h$, using the triangular inequality, we obtain

$$
\begin{aligned}
d\left(x_{n}, x_{m}\right) & \leq \sum_{k=n}^{m-1} d\left(x_{k}, x_{k+1}\right) \leq \sum_{k=n}^{m-1} \psi^{k}\left(q \psi\left(d\left(x_{0}, x_{1}\right)\right)\right) \\
& \leq \sum_{k \geq h}^{\infty} \psi^{k}\left(q \psi\left(d\left(x_{0}, x_{1}\right)\right)\right)<\epsilon
\end{aligned}
$$

and

$$
\begin{aligned}
d\left(y_{n}, y_{m}\right) & \leq \sum_{k=n}^{m-1} d\left(y_{k}, y_{k+1}\right) \leq \sum_{k=n}^{m-1} \psi^{k}\left(q^{\prime} \psi\left(d\left(y_{0}, y_{1}\right)\right)\right) \\
& \leq \sum_{k \geq h^{\prime}}^{\infty} \psi^{k}\left(q^{\prime} \psi\left(d\left(y_{0}, y_{1}\right)\right)\right)<\epsilon
\end{aligned}
$$

respectively. Hence $\left\{x_{n}\right\}$ and $\left\{y_{n}\right\}$ are Cauchy sequences in $A$. Similarly, one can show that $\left\{u_{n}\right\}$ and $\left\{v_{n}\right\}$ are Cauchy sequences in $B$. Since $A$ and $B$ are closed subsets of a complete metric space, there exists $\left(x^{*}, y^{*}\right)$ in $A \times A$ such that $x_{n} \rightarrow x^{*}, y_{n} \rightarrow y^{*}$ as $n \rightarrow \infty$ and there exist $u^{*}, v^{*}$ in $B$ such that $u_{n} \rightarrow u^{*}, v_{n} \rightarrow v^{*}$ as $n \rightarrow \infty$. By (37) and (38) we conclude that

$$
\begin{aligned}
& d\left(x^{*}, u^{*}\right)=\operatorname{dist}(A, B) \quad \text { as } n \rightarrow \infty \quad \text { and } \\
& d\left(y^{*}, v^{*}\right)=\operatorname{dist}(A, B) \quad \text { as } n \rightarrow \infty .
\end{aligned}
$$

Since $T$ is continuous and $u_{n} \in T\left(x_{n-1}, y_{n-1}\right)$, we have $u^{*} \in T\left(x^{*}, y^{*}\right)$ and $v_{n} \in T\left(y_{n-1}, x_{n-1}\right)$, we have $v^{*} \in T\left(y^{*}, x^{*}\right)$. Hence,

$$
\operatorname{dist}(A, B) \leq D\left(x^{*}, T\left(x^{*}, y^{*}\right)\right) \leq d\left(x^{*}, u^{*}\right)=\operatorname{dist}(A, B)
$$

and

$$
\operatorname{dist}(A, B) \leq D\left(y^{*}, T\left(y^{*}, x^{*}\right)\right) \leq d\left(y^{*}, v^{*}\right)=\operatorname{dist}(A, B) .
$$

Therefore, $\left(x^{*}, y^{*}\right)$ is the coupled best proximity point of the mapping $T$. 
Theorem 2.5 Let $A$ and $B$ be two nonempty closed subsets of a complete metric space $(X, d)$ such that $A_{0}$ is nonempty. Let $\alpha: A \times A \rightarrow[0, \infty)$ and let $T: A \times A \rightarrow \mathrm{K}(B)$ be a mapping satisfying the following conditions:

(i) $T(x, y) \subseteq B_{0}$ for each $(x, y) \in A_{0} \times A_{0}$ and $(A, B)$ satisfies the weak P-property;

(ii) $T$ is an $\alpha$-proximal admissible map;

(iii) there exist elements $\left(x_{0}, y_{0}\right),\left(x_{1}, y_{1}\right)$ in $A_{0} \times A_{0}$ and $u_{1} \in T\left(x_{0}, y_{0}\right), v_{1} \in T\left(y_{0}, x_{0}\right)$ such that

$$
\begin{array}{ll}
d\left(x_{1}, u_{1}\right)=\operatorname{dist}(A, B), & \alpha\left(x_{0}, x_{1}\right) \geq 1 \quad \text { and } \\
d\left(y_{1}, v_{1}\right)=\operatorname{dist}(A, B), & \alpha\left(y_{0}, y_{1}\right) \geq 1
\end{array}
$$

(iv) $T$ is a continuous $\alpha$ - $\psi$-proximal contraction.

Then there exists an element $\left(x^{*}, y^{*}\right) \in A_{0} \times A_{0}$ such that

$$
\begin{aligned}
& D\left(x^{*}, T\left(x^{*}, y^{*}\right)\right)=\operatorname{dist}(A, B) \quad \text { and } \\
& D\left(y^{*}, T\left(y^{*}, x^{*}\right)\right)=\operatorname{dist}(A, B) .
\end{aligned}
$$

Theorem 2.6 Let $A$ and $B$ be two nonempty closed subsets of a complete metric space $(X, d)$ such that $A_{0}$ is nonempty. Let $\alpha: A \times A \rightarrow[0, \infty)$ and let $\psi \in \Psi$ be a strictly increasing map. Suppose that $T: A \times A \rightarrow \mathrm{CL}(B)$ is a mapping satisfying the following conditions:

(i) $T(x, y) \subseteq B_{0}$ for each $(x, y) \in A_{0} \times A_{0}$ and $(A, B)$ satisfies the weak P-property;

(ii) $T$ is an $\alpha$-proximal admissible map;

(iii) there exist elements $\left(x_{0}, y_{0}\right),\left(x_{1}, y_{1}\right)$ in $A_{0} \times A_{0}$ and $u_{1} \in T\left(x_{0}, y_{0}\right), v_{1} \in T\left(y_{0}, x_{0}\right)$ such that

$$
\begin{array}{ll}
d\left(x_{1}, u_{1}\right)=d(A, B), & \alpha\left(x_{0}, x_{1}\right) \geq 1 \quad \text { and } \\
d\left(y_{1}, v_{1}\right)=d(A, B), & \alpha\left(y_{0}, y_{1}\right) \geq 1 ;
\end{array}
$$

(iv) property (C) holds and $T$ is an $\alpha$ - $\psi$-proximal contraction.

Then there exists an element $\left(x^{*}, y^{*}\right) \in A_{0} \times A_{0}$ such that

$$
\begin{aligned}
& D\left(x^{*}, T\left(x^{*}, y^{*}\right)\right)=\operatorname{dist}(A, B) \quad \text { and } \\
& D\left(y^{*}, T\left(y^{*}, x^{*}\right)\right)=\operatorname{dist}(A, B) .
\end{aligned}
$$

Proof Similar to the proof of Theorem 2.4, there exist Cauchy sequences $\left\{x_{n}\right\}$ and $\left\{y_{n}\right\}$ in $A$ and Cauchy sequences $\left\{u_{n}\right\}$ and $\left\{v_{n}\right\}$ in $B$ such that

$$
\begin{array}{ll}
d\left(x_{n+1}, u_{n+1}\right)=\operatorname{dist}(A, B), & \alpha\left(x_{n}, x_{n+1}\right) \geq 1 \quad \text { and } \\
d\left(y_{n+1}, v_{n+1}\right)=\operatorname{dist}(A, B), & \alpha\left(y_{n}, y_{n+1}\right) \geq 1 ;
\end{array}
$$

and $x_{n} \rightarrow x^{*} \in A, y_{n} \rightarrow y^{*} \in A$ as $n \rightarrow \infty$ and $u_{n} \rightarrow u^{*} \in B, v_{n} \rightarrow v^{*} \in B$ as $n \rightarrow \infty$.

From condition (C), there exist subsequences $\left\{x_{n_{k}}\right\}$ of $\left\{x_{n}\right\},\left\{y_{n_{k}}\right\}$ of $\left\{y_{n}\right\}$ such that $\alpha\left(x_{n_{k}}, x^{*}\right) \geq 1, \alpha\left(y_{n_{k}}, y^{*}\right) \geq 1$ for all $k$. Since $T$ is an $\alpha$ - $\psi$-proximal contraction, we have

$$
\begin{aligned}
H\left(T\left(x_{n_{k}}, y_{n_{k}}\right), T\left(x^{*}, y^{*}\right)\right) & \leq \alpha\left(x_{n_{k}}, x^{*}\right) H\left(T\left(x_{n_{k}}, y_{n_{k}}\right), T\left(x^{*}, y^{*}\right)\right) \\
& \leq \psi\left(d\left(x_{n_{k}}, x^{*}\right)\right), \quad \forall k,
\end{aligned}
$$


and

$$
\begin{aligned}
H\left(T\left(y_{n_{k}}, x_{n_{k}}\right), T\left(y^{*}, x^{*}\right)\right) & \leq \alpha\left(y_{n_{k}}, y^{*}\right) H\left(T\left(y_{n_{k}}, x_{n_{k}}\right), T\left(y^{*}, x^{*}\right)\right) \\
& \leq \psi\left(d\left(y_{n_{k}}, y^{*}\right)\right), \quad \forall k .
\end{aligned}
$$

Letting $k \rightarrow \infty$ in the above inequality, we get $T\left(x_{n_{k}}, y_{n_{k}}\right) \rightarrow T\left(x^{*}, y^{*}\right)$ and $T\left(y_{n_{k}}, x_{n_{k}}\right) \rightarrow$ $T\left(y^{*}, x^{*}\right)$, respectively. By the continuity of the metric $d$, we have

$$
\begin{aligned}
& d\left(x^{*}, u^{*}\right)=\lim _{k \rightarrow \infty} d\left(x_{n_{k}+1}, u_{n_{k}+1}\right)=\operatorname{dist}(A, B), \\
& d\left(y^{*}, v^{*}\right)=\lim _{k \rightarrow \infty} d\left(y_{n_{k}+1}, v_{n_{k}+1}\right)=\operatorname{dist}(A, B) .
\end{aligned}
$$

Since $u_{n_{k}+1} \in T\left(x_{n_{k}}, y_{n_{k}}\right), u_{n_{k}} \rightarrow u^{*}$ and $T\left(x_{n_{k}}, y_{n_{k}}\right) \rightarrow T\left(x^{*}, y^{*}\right)$, then $u^{*} \in T\left(x^{*}, y^{*}\right)$ and since $v_{n_{k}+1} \in T\left(y_{n_{k}}, x_{n_{k}}\right), v_{n_{k}} \rightarrow v^{*}$ and $T\left(y_{n_{k}}, x_{n_{k}}\right) \rightarrow T\left(y^{*}, x^{*}\right)$, then $v^{*} \in T\left(y^{*}, x^{*}\right)$. Hence,

$$
\operatorname{dist}(A, B) \leq D\left(x^{*}, T\left(x^{*}, y^{*}\right)\right) \leq d\left(x^{*}, u^{*}\right)=\operatorname{dist}(A, B)
$$

and

$$
\operatorname{dist}(A, B) \leq D\left(y^{*}, T\left(y^{*}, x^{*}\right)\right) \leq d\left(y^{*}, v^{*}\right)=\operatorname{dist}(A, B) .
$$

Therefore, $\left(x^{*}, y^{*}\right)$ is the coupled best proximity point of the mapping $T$.

Theorem 2.7 Let $A$ and $B$ be two nonempty closed subsets of a complete metric space $(X, d)$ such that $A_{0}$ is nonempty. Let $\alpha: A \times A \rightarrow[0, \infty)$ and let $T: A \times A \rightarrow \mathrm{K}(B)$ be a mapping satisfying the following conditions:

(i) $T(x, y) \subseteq B_{0}$ for each $(x, y) \in A_{0} \times A_{0}$ and $(A, B)$ satisfies the weak P-property;

(ii) $T$ is an $\alpha$-proximal admissible map;

(iii) there exist elements $\left(x_{0}, y_{0}\right),\left(x_{1}, y_{1}\right)$ in $A_{0} \times A_{0}$ and $u_{1} \in T\left(x_{0}, y_{0}\right), v_{1} \in T\left(y_{0}, x_{0}\right)$ such that

$$
\begin{array}{ll}
d\left(x_{1}, u_{1}\right)=\operatorname{dist}(A, B), & \alpha\left(x_{0}, x_{1}\right) \geq 1 \quad \text { and } \\
d\left(y_{1}, v_{1}\right)=\operatorname{dist}(A, B), & \alpha\left(y_{0}, y_{1}\right) \geq 1 ;
\end{array}
$$

(iv) property (C) holds and $T$ is an $\alpha$ - $\psi$-proximal contraction.

Then there exists an element $\left(x^{*}, y^{*}\right) \in A_{0} \times A_{0}$ such that

$$
\begin{aligned}
& D\left(x^{*}, T\left(x^{*}, y^{*}\right)\right)=\operatorname{dist}(A, B) \quad \text { and } \\
& D\left(y^{*}, T\left(y^{*}, x^{*}\right)\right)=\operatorname{dist}(A, B) .
\end{aligned}
$$

With a similar idea to the examples in [42], we give the following examples to support our main results.

Example 2.8 Let $X=[0, \infty) \times[0, \infty)$ be a product space endowed with the usual metric $d$. Suppose that $A=\left\{\left(\frac{1}{2}, x\right): 0 \leq x<\infty\right\}$ and $B=\{(0, x): 0 \leq x<\infty\}$. 
Define $T: A \times A \rightarrow \mathrm{CL}(B)$ by

$$
T\left(\left(\frac{1}{2}, a\right),\left(\frac{1}{2}, b\right)\right)= \begin{cases}\left\{\left(0, \frac{x}{2}\right): 0 \leq x \leq \max \{a, b\}\right\} & \text { if } a, b \leq 1 \\ \left\{\left(0, x^{2}\right): 0 \leq x \leq \max \left\{a^{2}, b^{2}\right\}\right\} & \text { if } a, b>1\end{cases}
$$

and define $\alpha: A \times A \rightarrow[0, \infty)$ by

$$
\alpha(x, y)= \begin{cases}1 & \text { if } x, y \in\left\{\left(\frac{1}{2}, a\right): 0 \leq a \leq 1\right\} \\ 0 & \text { otherwise }\end{cases}
$$

Let $\Psi(t)=\frac{t}{2}$ for all $t \geq 0$. Note that $A_{0}=A, B_{0}=B$, and $T(x, y) \subseteq B_{0}$ for each $(x, y) \in$ $A_{0} \times A_{0}$. Also, the pair $(A, B)$ satisfies the weak $P$-property.

Let $\left(x_{0}, y_{0}\right),\left(x_{1}, y_{1}\right) \in\left\{\left(\frac{1}{2}, x\right): 0 \leq x \leq 1\right\}^{2}$; then $T\left(x_{0}, y_{0}\right), T\left(x_{1}, y_{1}\right) \subseteq\left\{\left(0, \frac{x}{2}\right): 0 \leq x \leq 1\right\}$. Consider $u_{1} \in T\left(x_{0}, y_{0}\right), u_{2} \in T\left(x_{1}, y_{1}\right)$ and $w_{1}, w_{2} \in A$ such that $d\left(w_{1}, u_{1}\right)=\operatorname{dist}(A, B)$ and $d\left(w_{2}, u_{2}\right)=\operatorname{dist}(A, B)$. Then we have $w_{1}, w_{2} \in\left\{\left(\frac{1}{2}, x\right): 0 \leq x \leq \frac{1}{2}\right\}$, so $\alpha\left(w_{1}, w_{2}\right)=1$. And, for $v_{1} \in T\left(y_{0}, x_{0}\right), v_{2} \in T\left(y_{1}, x_{1}\right)$ and $w_{1}^{\prime}, w_{2}^{\prime} \in A$ such that $d\left(w_{1}^{\prime}, v_{1}\right)=\operatorname{dist}(A, B)$ and $d\left(w_{2}^{\prime}, v_{2}\right)=$ $\operatorname{dist}(A, B)$. Then we have $w_{1}^{\prime}, w_{2}^{\prime} \in\left\{\left(\frac{1}{2}, x\right): 0 \leq x \leq \frac{1}{2}\right\}$, so $\alpha\left(w_{1}^{\prime}, w_{2}^{\prime}\right)=1$. Therefore, $T$ is an $\alpha$ proximal admissible map. For $\left(x_{0}, y_{0}\right)=\left(\left(\frac{1}{2}, 1\right),\left(\frac{1}{2}, 1\right)\right) \in A_{0} \times A_{0}$ and $u_{1}=\left(0, \frac{1}{2}\right) \in T\left(x_{0}, y_{0}\right)$, $v_{1}=\left(0, \frac{1}{4}\right) \in T\left(y_{0}, x_{0}\right)$ in $B_{0}$, we have $\left(x_{1}, y_{1}\right)=\left(\left(\frac{1}{2}, \frac{1}{2}\right),\left(\frac{1}{2}, \frac{1}{4}\right)\right) \in A_{0} \times A_{0}$ such that

$$
d\left(x_{1}, u_{1}\right)=\operatorname{dist}(A, B), \quad \alpha\left(x_{0}, x_{1}\right)=\alpha\left(\left(\frac{1}{2}, 1\right),\left(\frac{1}{2}, \frac{1}{2}\right)\right)=1
$$

and

$$
d\left(y_{1}, v_{1}\right)=\operatorname{dist}(A, B), \quad \alpha\left(y_{0}, y_{1}\right)=\alpha\left(\left(\frac{1}{2}, 1\right),\left(\frac{1}{2}, \frac{1}{4}\right)\right)=1
$$

If $x, x^{\prime}, y, y^{\prime} \in\left\{\left(\frac{1}{2}, a\right): 0 \leq a \leq 1\right\}^{2}$, then we have

$$
\alpha(x, y) H\left(T\left(x, x^{\prime}\right), T\left(y, y^{\prime}\right)\right)=\frac{|x-y|}{2}=\frac{1}{2} d(x, y)=\psi(d(x, y)),
$$

for otherwise

$$
\alpha(x, y) H\left(T\left(x, x^{\prime}\right), T\left(y, y^{\prime}\right)\right) \leq \psi(d(x, y))
$$

Hence, $T$ is an $\alpha$ - $\psi$-proximal contraction. Moreover, if $\left\{x_{n}\right\}$ is a sequence in $A$ such that $\alpha\left(x_{n}, x_{n+1}\right)=1$ for all $n$ and $x_{n} \rightarrow x \in A$ as $n \rightarrow \infty$, then there exists a subsequence $\left\{x_{n_{k}}\right\}$ of $\left\{x_{n}\right\}$ such that $\alpha\left(x_{n_{k}}, x\right)=1$ for all $k$. Therefore, all the conditions of Theorem 2.6 hold and $T$ has the coupled best proximity point.

Example 2.9 Let $X=[0, \infty) \times[0, \infty)$ be endowed with the usual metric $d$. Let $a>1$ be any fixed real number, $A=\{(a, x): 0 \leq x<\infty\}$ and $B=\{(0, x): 0 \leq x<\infty\}$. Define $T: A \times A \rightarrow$ $\mathrm{CL}(B)$ by

$$
T((a, x),(a, y))=\left\{\left(0, b^{2}\right): 0 \leq b \leq \max \{x, y\}\right\}
$$


and $\alpha: A \times A \rightarrow[0, \infty)$ by

$$
\alpha((a, x),(a, y))= \begin{cases}1 & \text { if } x=y=0 \\ \frac{1}{a(x+y)} & \text { otherwise. }\end{cases}
$$

Let $\psi(t)=\frac{t}{a}$ for all $t \geq 0$. Note that $A_{0}=A, B_{0}=B$ and $T(x, y) \in B_{0}$ for each $x, y \in A_{0}$. If $w_{1}=\left(a, y_{1}\right), w_{1}^{\prime}=\left(a, y_{1}^{\prime}\right), w_{2}=\left(a, y_{2}\right), w_{2}^{\prime}=\left(a, y_{2}^{\prime}\right) \in A$ with either $y_{1} \neq 0$ or $y_{2} \neq 0$ or both are nonzero, we have

$$
\begin{aligned}
\alpha\left(w_{1}, w_{2}\right) H\left(T\left(w_{1}, w_{1}^{\prime}\right), T\left(w_{2}, w_{2}^{\prime}\right)\right) & =\frac{1}{a\left(y_{1}+y_{2}\right)}\left|y_{1}^{2}-y_{2}^{2}\right| \\
& =\frac{1}{a}\left|y_{1}-y_{2}\right| \\
& =\psi\left(d\left(w_{1}, w_{2}\right)\right)
\end{aligned}
$$

for otherwise

$$
\alpha\left(w_{1}, w_{2}\right) H\left(T\left(w_{1}, w_{1}^{\prime}\right), T\left(w_{2}, w_{2}^{\prime}\right)\right)=0=\psi\left(d\left(w_{1}, w_{2}\right)\right) .
$$

For $x_{0}=\left(a, \frac{1}{2 a}\right), y_{0}=\left(a, \frac{1}{3 a}\right) \in A_{0}$ and $u_{1}=\left(0, \frac{1}{4 a^{2}}\right) \in T\left(x_{0}, y_{0}\right)$ such that $d\left(x_{1}, u_{1}\right)=a=$ $\operatorname{dist}(A, B)$ and $\alpha\left(x_{0}, x_{1}\right)=\frac{4 a}{1+2 a}>1$. And for $x_{1}=\left(a, \frac{1}{3 a}\right), y_{1}=\left(a, \frac{1}{9 a^{2}}\right) \in A_{0}$ and $v_{1}=\left(0, \frac{1}{9 a^{2}}\right) \in$ $T\left(x_{1}, y_{1}\right)$ such that $d\left(y_{1}, v_{1}\right)=a=\operatorname{dist}(A, B)$ and $\alpha\left(y_{0}, y_{1}\right)=\frac{9 a}{1+3 a}>1$. Furthermore, one can see that the remaining conditions of Theorem 2.4 also hold. Therefore, $T$ has the coupled best proximity point.

\section{Competing interests}

The author declares that he has no competing interests.

\section{Acknowledgements}

The author is grateful to Lampang Rajabhat University for financial support during the preparation of this manuscript and to the referees for useful suggestions.

Received: 11 November 2014 Accepted: 4 February 2015 Published online: 24 February 2015

\section{References}

1. Arvanitakis, AD: A proof of the generalized Banach contraction conjecture. Proc. Am. Math. Soc. 131(12), 3647-3656 (2003)

2. Boyd, DW, Wong, JSW: On nonlinear contractions. Proc. Am. Math. Soc. 20, 458-464 (1969)

3. Choudhury, BS, Das, KP: A new contraction principle in Menger spaces. Acta Math. Sin. 24(8), 1379-1386 (2008)

4. Mongkolkeha, C, Sintunavarat, W, Kumam, P: Fixed point theorems for contraction mappings in modular metric spaces. Fixed Point Theory Appl. 2011, Article ID 93 (2011)

5. Sintunavarat, W, Kumam, P: Gregus type fixed points for a tangential multi-valued mappings satisfying contractive conditions of integral type. J. Inequal. Appl. 2011, Article ID 3 (2011)

6. Suzuki, T: A generalized Banach contraction principle that characterizes metric completeness. Proc. Am. Math. Soc. 136(5), 1861-1869 (2008)

7. Samet, B, Vetro, C, Vetro, P: Fixed point theorems for $\alpha-\psi$-contractive type mappings. Nonlinear Anal., Theory Methods Appl. 75(4), 2154-2165 (2012)

8. Karapınar, E, Samet, B: Generalized $\alpha-\psi$ contractive type mappings and related fixed point theorems with applications. Abstr. Appl. Anal. 2012, Article ID 793486 (2012)

9. Asl, JH, Rezapour, S, Shahzad, N: On fixed points of $\alpha$ - $\psi$-contractive multifunctions. Fixed Point Theory Appl. 2012 , Article ID 212 (2012)

10. Mohammadi, B, Rezapour, S, Shahzad, N: Some results on fixed points of ( $\alpha$ - $\psi$ )-Ćirić generalized multifunctions. Fixed Point Theory Appl. 2013, Article ID 24 (2013)

11. Ali, MU, Kamran, T: On $\left(\alpha^{*}, \psi\right)$-contractive multi-valued mappings. Fixed Point Theory Appl. 2013, Article ID 137 (2013) 
12. Amiri, P, Rezapour, S, Shahzad, N: Fixed points of generalized $(\alpha-\psi)$-contractions. Rev. R. Acad. Cienc. Exactas Fís. Nat., Ser. A Mat. 108(2), 519-526 (2014)

13. Minak, G, Altun, I: Some new generalizations of Mizoguchi-Takahashi type fixed point theorem. J. Inequal. Appl. 2013 Article ID 493 (2013)

14. Ali, MU, Kamran, T, Sintunavarat, W, Katchang, P: Mizoguchi-Takahashi's fixed point theorem with $\alpha, \eta$ functions. Abstr. Appl. Anal. 2013, Article ID 418798 (2013)

15. Chen, CM, Karapınar, E: Fixed point results for the $\alpha$-Meir-Keeler contraction on partial Hausdorff metric spaces. J. Inequal. Appl. 2013, Article ID 410 (2013)

16. Ali, MU, Kamran, T, Karapınar, E: $(\alpha, \psi, \xi)$-Contractive multivalued mappings. Fixed Point Theory Appl. 2014, Article ID 7 (2014)

17. Ali, MU, Kamran, T, Karapınar, E: A new approach to $(\alpha-\psi)$-contractive nonself multivalued mappings. J. Inequal. Appl. 2014, Article ID 71 (2014)

18. Ali, MU, Kiran, Q, Shahzad, N: Fixed point theorems for multi-valued mappings involving $\alpha$-function. Abstr. Appl. Anal. 2014, Article ID 409467 (2014)

19. Jleli, M, Samet, B: Best proximity points for $(\alpha-\psi)$-proximal contractive type mappings and applications. Bull. Sci. Math. 137(8), 977-995 (2013)

20. Abkar, A, Gabeleh, M: Best proximity points for asymptotic cyclic contraction mappings. Nonlinear Anal. 74(18), 7261-7268 (2011)

21. Abkar, A, Gabeleh, M: Best proximity points for cyclic mappings in ordered metric spaces. J. Optim. Theory Appl. 151(2), 418-424 (2011)

22. Abkar, A, Gabeleh, M: The existence of best proximity points for multivalued non-self mappings. Rev. R. Acad. Cienc Exactas Fís. Nat., Ser. A Mat. 107(2), 319-325 (2012)

23. Alghamdi, MA, Shahzad, N: Best proximity point results in geodesic metric spaces. Fixed Point Theory Appl. 2012, Article ID 234 (2012)

24. Al-Thagafi, MA, Shahzad, N: Best proximity pairs and equilibrium pairs for Kakutani multimaps. Nonlinear Anal., Theory Methods Appl. 70(3), 1209-1216 (2009)

25. Al-Thagafi, MA, Shahzad, N: Convergence and existence results for best proximity points. Nonlinear Anal., Theory Methods Appl. 70(10), 3665-3671 (2009)

26. Al-Thagafi, MA, Shahzad, N: Best proximity sets and equilibrium pairs for a finite family of multimaps. Fixed Point Theory Appl. 2008, Article ID 457069 (2008)

27. Derafshpour, M, Rezapour, S, Shahzad, N: Best proximity points of cyclic $\varphi$-contractions in ordered metric spaces. Topol. Methods Nonlinear Anal. 37(1), 193-202 (2011)

28. Di Bari, C, Suzuki, T, Vetro, C: Best proximity points for cyclic Meir-Keeler contractions. Nonlinear Anal., Theory Methods Appl. 69, 3790-3794 (2008)

29. Eldred, AA, Veeramani, P: Existence and convergence of best proximity points. J. Math. Anal. Appl. 323, 1001-1006 (2006)

30. Markin, J, Shahzad, N: Best proximity points for relatively u-continuous mappings in Banach and hyperconvex spaces Abstr. Appl. Anal. 2013, Article ID 680186 (2013)

31. Rezapour, S, Derafshpour, M, Shahzad, N: Best proximity points of cyclic $\phi$-contractions on reflexive Banach spaces. Fixed Point Theory Appl. 2010, Article ID 946178 (2010)

32. Basha, SS, Shahzad, N, Jeyaraj, R: Best proximity point theorems for reckoning optimal approximate solutions. Fixed Point Theory Appl. 2012, Article ID 202 (2012)

33. Vetro, C: Best proximity points: convergence and existence theorems for $p$-cyclic mappings. Nonlinear Anal., Theory Methods Appl. 73, 2283-2291 (2010)

34. Zhang, J, Su, Y, Cheng, Q: A note on 'A best proximity point theorem for Geraghty-contractions'. Fixed Point Theory Appl. 2013, Article ID 83 (2013)

35. Mongkolkeha, C, Kumam, P: Best proximity point theorems for generalized cyclic contractions in ordered metric spaces. J. Optim. Theory Appl. 155, 215-226 (2012)

36. Sintunavarat, W, Kumam, P: Coupled best proximity point theorem in metric spaces. Fixed Point Theory Appl. 2012, Article ID 93 (2012)

37. Nashine, HK, Vetro, C, Kumam, P: Best proximity point theorems for rational proximal contractions. Fixed Point Theory Appl. 2013, Article ID 95 (2013)

38. Cho, YJ, Gupta, A, Karapınar, E, Kumam, P, Sintunavarat, W: Tripled best proximity point theorem in metric spaces. Math. Inequal. Appl. 16, 1197-1216 (2013)

39. Mongkolkeha, C, Kongban, C, Kumam, P: Existence and uniqueness of best proximity points for generalized almost contractions. Abstr. Appl. Anal. 2014, Article ID 813614 (2014)

40. Kumam, P, Salimi, P, Vetro, C: Best proximity point results for modified $\alpha$-proximal c-contraction mappings. Fixed Point Theory Appl. 2014, Article ID 99 (2014)

41. Pragadeeswarar, V, Marudai, M, Kumam, P, Sitthithakerngkiet, K: The existence and uniqueness of coupled best proximity point for proximally coupled contraction in a complete ordered metric space. Abstr. Appl. Anal. 2014 Article ID 274062 (2014)

42. Ali, MU, Kamran, T, Shahzad, N: Best proximity point for $\alpha$ - $\psi$-proximal contractive multimap. Abstr. Appl. Anal. 2014 Article ID 181598 (2014) 